\title{
Lumen
}

Selected Proceedings from the Canadian Society for Eighteenth-Century Studies

\section{Sixpenny State? Cheap Print and Cultural-political Citizenship in the Onset of Modernity}

\section{Gary Kelly}

Volume 36, 2017

URI : https://id.erudit.org/iderudit/1037853ar

DOI : https://doi.org/10.7202/1037853ar

Aller au sommaire du numéro

Éditeur(s)

Canadian Society for Eighteenth-Century Studies / Société canadienne d'étude du dix-huitième siècle

ISSN

1209-3696 (imprimé)

1927-8284 (numérique)

Découvrir la revue

Citer cet article

Kelly, G. (2017). Sixpenny State? Cheap Print and Cultural-political Citizenship in the Onset of Modernity. Lumen, 36, 37-61. https://doi.org/10.7202/1037853ar 


\section{Sixpenny State? Cheap Print and Cultural-political Citizenship in the Onset of Modernity}

GARY KeLLY

University of Alberta

Informed by integrational linguistics and effective semiotics, ${ }^{1}$ this essay converges histories of the production and circulation of print, of the social and cultural meaning of money, of reading, and of cultural citizenship. It does so to suggest that, in the late eighteenth and early nineteenth century, certain kinds of print could be deployed by their purchasers, readers, and users to create certain kinds of culturalpolitical citizenship in the onset of modernity and formation of the modern state. Modernity is here understood as a contested discourse comprising self-reflexive personal identity able to engage in "pure" or ostensibly disinterested relationships of intimacy, conjugality, domesticity, and sociability. These in turn supposedly enabled success in managing modernity's intensified relations of risk and trust, more complex abstract systems from finance to government, ever-changing chronotopes or configurations of time-space from home through "nation" to empire, and pressures to disembed from customary identities, relations, and locations and re-embed in new, unfamiliar, and ever-changing modern ones. "Cultural citizenship" has been used

1. Roy Harris, The Language Myth (London: Duckworth, 1981), among others; Alec McHoul, Semiotic Investigations: Towards an Effective Semiotics (Lincoln, Neb.: University of Nebraska Press, 1996).

2. I adapt the account in Anthony Giddens, The Consequences of Modernity (Stanford CA: Stanford University Press, 1990), to see modernity as a discourse and field of contest rather than a comprehensive and monolithic condition and process. 
since the 1980 s to indicate meanings made by certain people from and through social and cultural practices, including "consumption," often as a basis for larger claims to political citizenship and other rights. ${ }^{3}$ For the onset of modernity, recent scholarship has focused more on political print's role in assembling of a reformist agenda and "public sphere" than on cheap print's wider uses in creating such a sense of cultural citizenship in formation of the modern constitutional state. ${ }^{4}$ There are various ways of taxonomizing print, but to explore such uses this essay considers print less in relation to authors, themes, ideas, innovations, engagements, reception, reviews, and so on than to leading producers and likely purchasers and users of print around a major "price point." This was a price corresponding to certain purchasers' material ability and socio-culturally established willingness to pay. During the onset of modernity, and indeed for generations before and after, one important such price point for a print object was sixpence.

The United Kingdom's 1971 transition to decimal currency soon flushed from English a pejorative meaning of the adjective "sixpenny" going back to the sixteenth century at least, as "worth only sixpence; paltry, petty" (OED). Such usage is found throughout the eighteenth century. The sixpence was a piece of money, when a labourer's weekly wage would be five to ten shillings (or ten to twenty sixpences). ${ }^{5}$ Further, the epithet "sixpenny" could be merely descriptive, indicating a certain quantity, kind, size, or extent of goods or services, such as sixpenny worth of punch, a sixpenny brick, a sixpenny loaf, or a sixpenny coach ride. But money's meaning is always social and cultural. ${ }^{6}$

3. See for example M. Sharon Jeannotte, "Just Showing Up: Social and Cultural Capital in Everyday Life," and Karim H. Karim, "The Elusiveness of Full Citizenship: Accounting for Cultural Capital, Cultural Competencies, and Cultural Pluralism," in Accounting for Culture: Thinking through Cultural Citizenship, ed. Caroline Andrew, Monica Gattinger, and M. Sharon Jeannotte (Ottawa: University of Ottawa Press, 2005), 124-45, 146-58.

4. See Judith Stoddart, "Cultures of Print: Mass Markets and Theories of the Liberal Public Sphere," in Authorship, Commerce and the Public Sphere: Scenes of Writing, 1750-1850, ed. E. J. Clery, Caroline Franklin, and Peter Garside (Basingstoke and New York: Palgrave Macmillan, 2002), 171-85.

5. William St Clair, The Reading Nation in the Romantic Period (Cambridge: Cambridge University Press, 2004), 195-96; but see also the estimate that a London labourer could expect ten shillings a week in this period, in L. D. Schwarz, London in the Age of Industrialisation (Cambridge: Cambridge University Press, 1992), 161-78.

6. See Viviana Zelizer, The Social Meaning of Money (New York: Basic Books, 1994). 
The sixpenny price point was deeply imbricated in social and cultural difference and hierarchy, and so the descriptive could easily become pejorative. A sixpenny loaf was a common allotment to the poor or incarcerated.7 A "sixpenny trull" was the cheapest and implicitly most wretched of prostitutes. ${ }^{8}$ A "sixpenny fardle" was a peddler's bundle of cheap goods. . A "sixpenny ordinary" was a cheap eating and drinking house..$^{10}$ A "sixpenny pricker" was a mountebank doctor. ${ }^{11}$ A "sixpenny bargain" was an insignificant commercial transaction. ${ }^{12}$ A "sixpenny pamphlet" was a common eighteenth- and nineteenth-century print object, but the phrase was often used disparagingly. ${ }^{13}$

With the crisis of the American and French Revolutionary wars and proliferation of controversial print alongside perceived growth in the reading public, the pejorative sense of "sixpenny" was increasingly applied to politics and print, together. Many among social elites came to associate sixpenny print with popularization, vulgarization, and demagoguery, indicating growing anxiety at convergence of increased literacy, cheap print, and plebeian political mobilization whether "loyalist" or "reformist." A 1790 attack on the prominent Dissenter and scientist Joseph Priestley by a former royal chaplain referred contemptuously to Priestley's reformist pamphleteering as "little sixpenny squibs." 14 The 1797 Anti-Jacobin novel Vaurien derided the Jacobin orator Rant's “sixpenny eloquence."15 A 1797 attack on Paine's Age of Reason denounced "those warehouses of scepticism, where a sixpenny

7. "Country News," London Daily Advertiser, Thu. 2 Jan. 1752 [2].

8. Thomas Baker, The Humour of the Age: A Comedy (London: R. Wellington, B. Lintot, and A. Bettesworth, 1701), 43.

9. No King-Sellers; or, A Brief Detection of the Vanity and Villany [sic] in a Sermon, entitul'd No King-Killers (London: T. Roberts, 1715), 8.

10. Simon Linguet, Memoirs of the Bastille (Dublin: J. A. Husband, 1783), 56 .

11. Chimaira: The New Artillery; or, Medicinal Battery (London: for T. Payne, and sold by J. Morphew, 1718), 1.

12. "Isaac Broadloom," The Hue and Cry of the Poor of Ireland for Small Change (Dublin: n. p., 1731), 3.

13. David Williams, Lectures on Education, 4 vols (London: John Bell, 1789), vol. 2,42 .

14. Spencer Madan, A Letter to Doctor Priestley, in Consequence of his "Familiar Letters addressed to the Inhabitants of the Town of Birmingham, E.c." (Birmingham: E. Piercy, 1790), 39 .

15. Isaac D'Israeli, Vaurien; or, Sketches of the Times: exhibiting Views of the Philosophies, Religions, Politics, Literature, and Manners of the Age, 2 vols (London:

T. Cadell and W. Davies; J. Murray and S. Highley, 1797), vol. 2, 109. 
orator harangues upon the beauties of Thomas Paine, and bespatters the Bible with all the beauties of Billingsgate."16 An 1800 account of The Rise and Dissolution of the Infidel Societies in London attributed spread of disloyalty to Church and King to "repeated publication" of the translated works of Voltaire in "sixpenny numbers." ${ }^{17}$ Such political print became central to reformist networks and associations. ${ }^{18}$ In return it and sixpenny print in general incurred the suspicion of government, loyalist vigilante societies, Church-and-King magistrates, counterrevolutionary polemicists, and parliamentary legislators, who proceeded to harass, prosecute, tax, and ban accordingly.

"Sixpenny" could acquire these meanings because sixpence was, had been, and would remain what is now called a price point and was then called a "touch," or price that would elicit purchase of a certain object, quantity of goods, or service in a certain market. Booksellers had used "sixpenny touch" since the early eighteenth century to designate a certain print object, typically a pamphlet. ${ }^{19}$ Their ability to offer such objects was enhanced by late eighteenth- and early nineteenth-century social and cultural changes and legal, technological, and commercial innovations. These were prompted by and served the onset of modernity and included increased population and number of the literate, rising prestige of print culture, ending of claims to perpetual copyright, encroachment by outsiders on the London publishers cabal, development of distribution infrastructure from roads and canals to railways, sophistication and spread to the provinces of publishing in sixpenny serial "numbers" and "parts," and invention of the iron press, stereotyping, the steam-powered press, mechanical papermaking, engraving on boxwood and steel, and cloth binding, culminating with wood-pulp paper in the 1840 o. At the beginning of this transformation the sixpenny touch was a pamphlet; by its culmination it was a full-length book.

16. John Padman, A Layman's Protest against the Profane Blasphemy, false Charges, and illiberal Invective of Thomas Paine, Author of a Book, entitled The Age of Reason (London: for the Author), 229.

17. Op. cit. (London: J. Hatchard, 1800), 88.

18. Jon Mee, Print, Publicity, and Popular Radicalism in the 179os: The Laurel of Liberty (Cambridge: Cambridge University Press, 2016), 7.

19. See Jonathan Swift, Political Tracts, 2 vols (London: C. Davis, 1738), vol. 2, 55. 


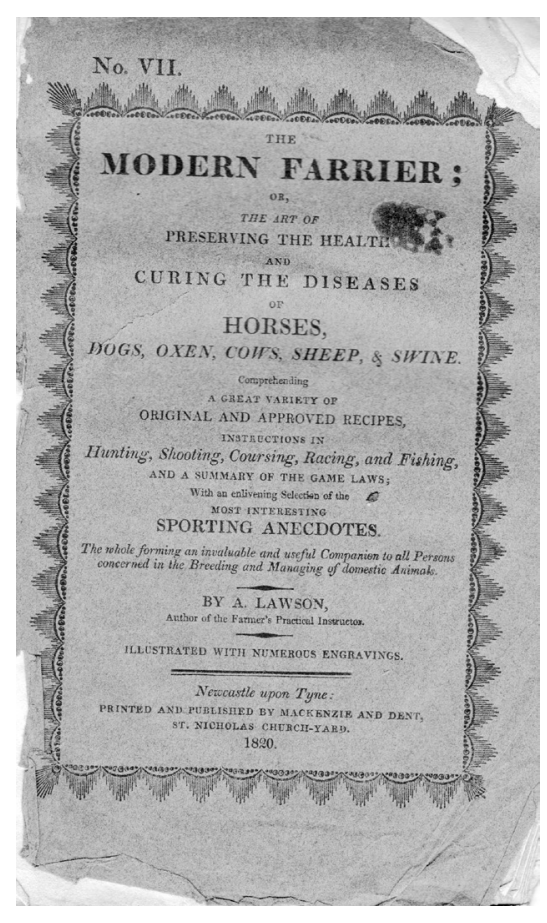

Modernized practical knowledges in sixpenny numbers, incorporating hobbies and fun: Modern Farriery (Newcastle upon Tyne: Mackenzie and Dent, 1820), number 7.

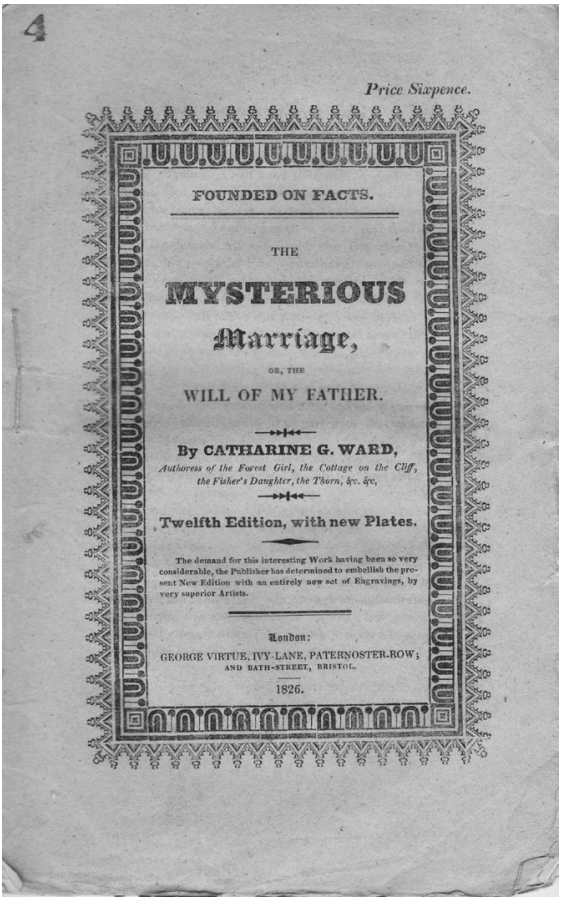

Titillating novels in sixpenny numbers: Catherine G. Ward, The Mysterious Marriage (London: George Virtue, 1826), number 4.

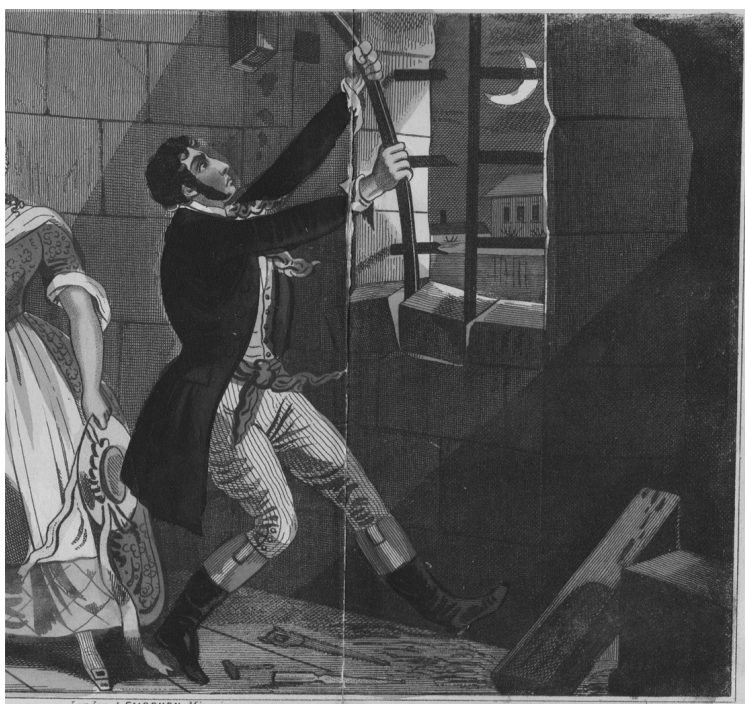

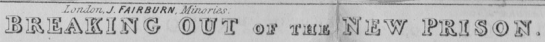

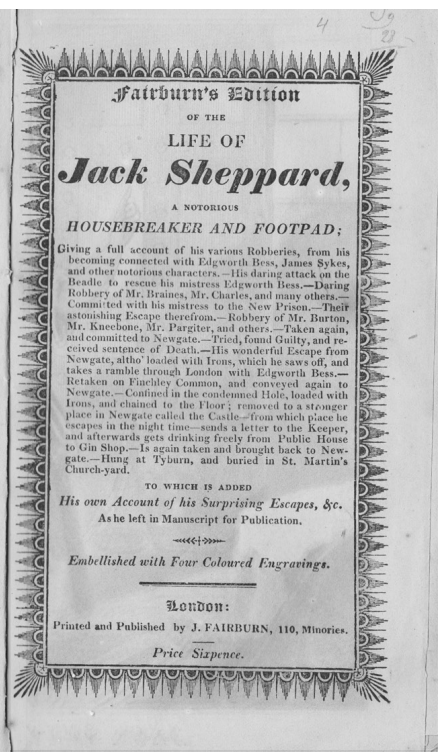

Familiar Newgate literature in sixpenny pamphlets: Jack Shepherd. 


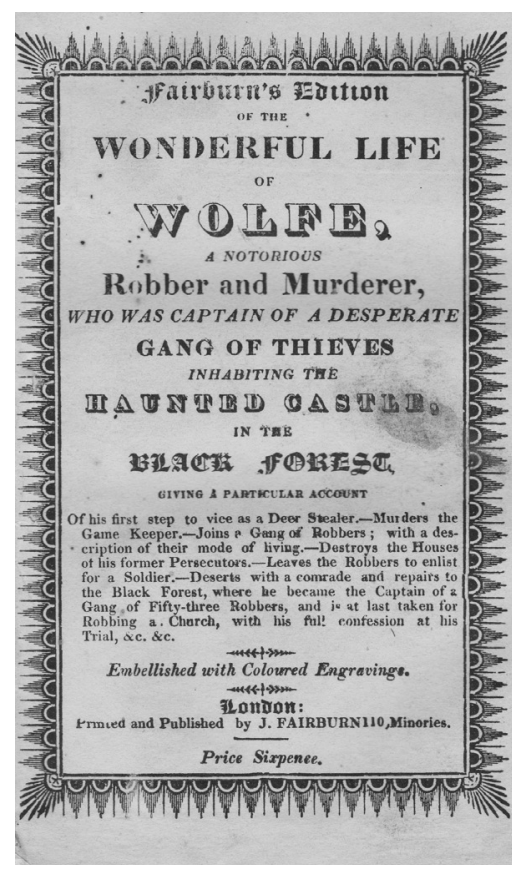

Abbreviated Gothic novels and adapted plays in sixpenny pamphlets: Wolfe, Fairburn's Edition.

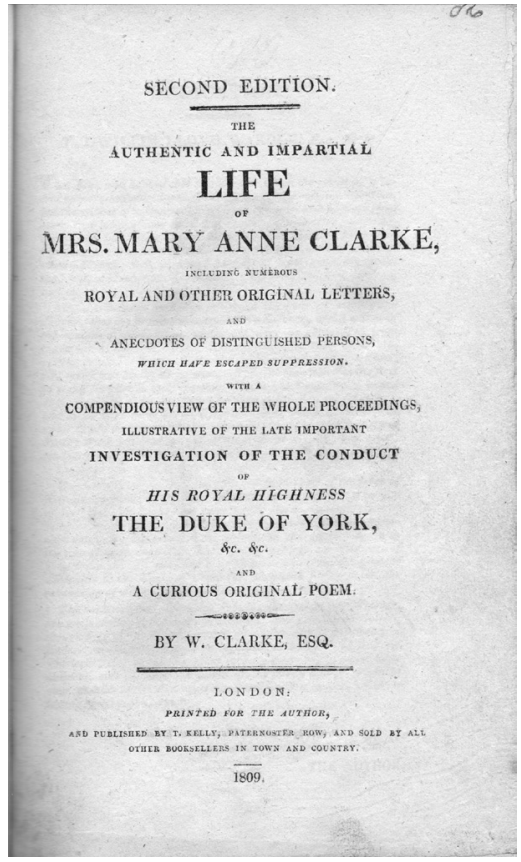

Royal scandal and current events: Duke of York's former mistress accused of selling army commissions (London: Thomas Kelly, 1809).
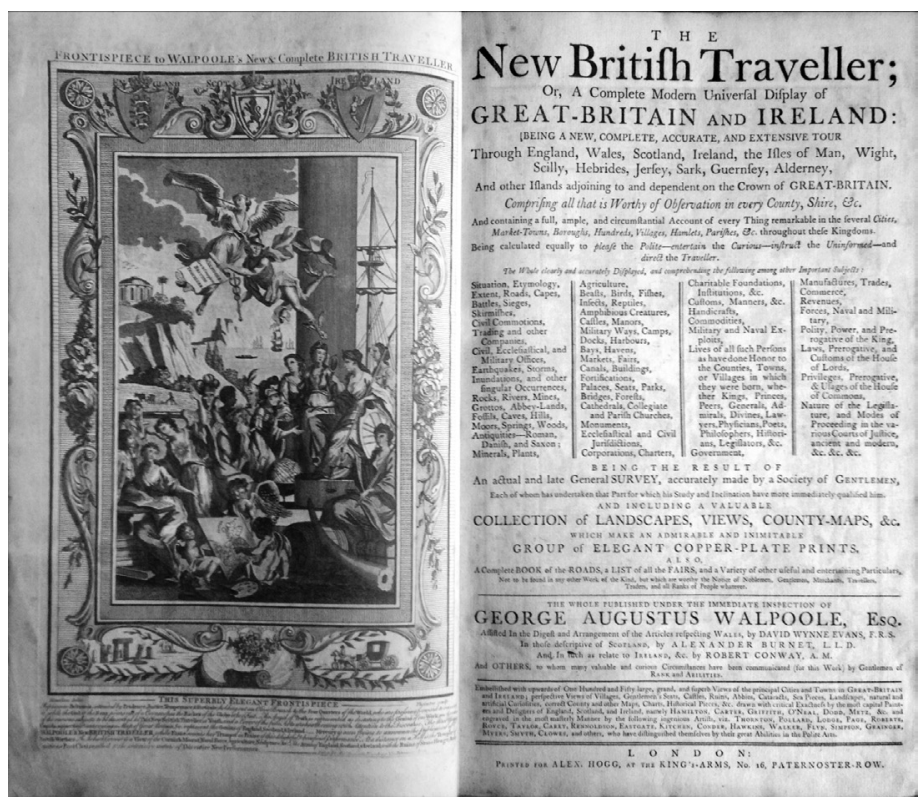

Modern chronotopes in sixpenny numbers: "George Augustus Walpoole," The New British Traveller (London: Alex Hogg, n. d.). 
Culturally, the sixpenny touch was customary, or embedded in patterns and economies of everyday life. People had long paid sixpence for a certain kind of print object and long continued to do so, and though cheap print sold at various prices, sixpenny formats seem to have predominated, especially down market. The commonness and longevity of the sixpenny price point in this market suggest that competition in it depended on offering what would be perceived as a more substantial, better quality, more up-to-date, or fashionable product for this price rather than on offering a similar product at somewhat lower price. In this respect the sixpence resembled the dime of nineteenthcentury and "two-bits" (twenty-five cents) of twentieth-century popular print culture. Perceptually, the sixpenny touch likely depended more on the socio-cultural than the exchange value of money. Meaning does not reside once-and-for-all in objects and utterances but is created by their users in particular instances in and for everyday life. ${ }^{20}$ If such meaning-making could help constitute individual and group sense of identity and cultural citizenship, and cultural citizenship could ground aspirations to and demands for political citizenship and social and economic justice, then through the late eighteenth- and early nineteenth-century onset of modernity users of sixpenny print had an increasing and diversifying body of such sixpenny objects to use in this way. For such readers/users these objects would constitute a megatext, and though recent scholarship of this period focuses on "literary" or on political print, the sixpenny megatext included but went far beyond that. ${ }^{21}$

Most prominent was religious print, apparently targeting a neopuritanism spanning New Dissent (outside the established church) and Methodism (still largely within the established church) in England and "seceders" in Scotland and Ireland, and mainly comprising members

20. See McHoul, Semiotic Investigations, ch. 5, "Reading Practices" (65-87).

21. St Clair, Reading Nation; Thomas F. Bonnell, The Most Disreputable Trade: Publishing the Classics of English Poetry 1765-1810 (Oxford: Oxford University Press, 2008); Ian Haywood, The Revolution in Popular Print: Print, Politics and the People, 1790-1860 (Cambridge: Cambridge University Press, 2004); Paul Keen, The Crisis of Literature in the 179os: Print Culture and the Public Sphere (Cambridge: Cambridge University Press, 1999), and Literature, Commerce, and the Spectacle of Modernity, 1750-180o (Cambridge: Cambridge University Press, 2012); Mee, Print, Publicity, and Popular Radicalism. 
of the artisanate, farming tenantry, and shopocracy. ${ }^{22}$ Pre-eminent among the neo-puritan texts were editions of the Bible in sixpenny weekly numbers or larger, less frequent, and more expensive parts, illustrated with copper engravings after or in the style of old masters. Such editions were often sub-titled "self-interpreting" but typically included commentary by a famous Protestant Dissenting minister such as the Scots independent Presbyterian John Brown or the Swiss Protestant Jean-Frédéric Osterwald. Alongside neo-puritan Bibles came new sixpenny-number editions of seventeenth- and early eighteenth-century puritan and Dissenting writers such as the "Bunyan, Brown, an' Boston" derided by Robert Burns. ${ }^{23}$ There were sixpenny sermons aplenty. There were sixpenny-number editions of more recent pietistic and sentimental works such as Edward Young's The Complaint; or, Night-Thoughts, Christoph Christian Sturm's Reflections for Every Day in the Year on the Works of God, Friedrich Gottlieb Klopstock's The Messiah, James Hervey's Meditations among the Tombs, and the anonymous Dialogues between a Pilgrim, Adam, Noah, and Cleophas.

The resulting sixpenny religious megatext was widely circulated and could be used by neo-puritans to formulate a transcendentally validated cultural citizenship, or sense of self-worth, collective identity, and rights based on shared religious-cultural artifacts and practices. They could use the sixpenny religious megatext to fashion a conversion-based modern self-reflexive personal identity and guide to modern "pure" relationships and sociability. They could use it for confidence in facing modern situations of risk and trust. They could use it to envision their place in a chronotope comprising human time up to the increasingly unstable present. In short, they could use the megatext as manual for a plebeian and lower middle-class modernity, consciously distinct from and largely rejecting the customary and hence "unmodern" culture of their non-puritan peers, superior to the perceived "irreligion" or theological "error" of their social "betters," and distinct from the "respectable" and tempered piety of those of their energetically modernizing middle-class contemporaries who adhered to Old

22. See A. D. Gilbert, Religion and Society in Industrial England: Church, Chapel, and Social Change 1740-1914 (London and New York: Longman, 1976), $23-48$.

23. Robert Burns, "Epistle to James Tennant of Glenconner," 1. 22, referring to John Bunyan, John Brown, and Thomas Boston. 
Dissent or the new established-church Evangelicalism. Most important, such readers could use this religious megatext to ground their acquisition in sixpenny numbers and pamphlets of modern knowledges otherwise available only at prices that effectively excluded the sixpenny readership. Modernization itself, as the late eighteenth- early nineteenth-century commercial and technological publishing revolution, increasingly put such modern knowledges within reach of sixpence.

Perhaps the most prominent such knowledge was "modern history." If the neo-puritan religious megatext could enable some members of the artisanate and lower-middling sort to create an affordable and distinctive version for modernity of the national religion, analogous products could offer such readers and many more in their ranks a similarly distinctive and affordable "modern" version of the "national" history, identity, and destiny. Modernizers high and low required a specifically modern history in order to validate themselves as modern and to consign anyone else to the unmodern, past and present. ${ }^{24}$ But modernizers upmarket and down also needed modern history to assert a certain continuity between past and future, via the present. Finally, modernizers needed a "national" history to fashion a new geo-socio-political chronotope serving their interests. Wide circulation of such history preceded and accompanied formation of the modern state. Through the onset of modernity the need for such history was met mainly by the avowedly modern histories of England by Hume and Smollett, initially targeting elites. The sixpenny-number trade responded with pastiches and plagiarisms, illustrated and melodramatizing major events, and updated to the year of a particular edition, usually at a particular conjuncture in the onrolling crisis of nation and empire under modernization in global conflict. Advertisements and surviving copies suggest that, like number-trade Bibles, number-trade "national" histories were to be bound in varying degrees of lavishness as "furniture" books for display in the home to oneself, family, friends, and professional or business associates, with several possible uses. These might include conscious participation in a certain modernity, commitment to a certain vision of nation and empire, material-cultural token of domestic prosperity and stability, assertion of membership in a

24. See Reinhart Koselleck, Futures Past: On the Semantics of Historical Time, trans. Keith Tribe (New York: Columbia University Press, 2004), ch. 1. 
certain social formation, as reference works for political and ideological commitments, as a major symbol of cultural-national citizenship, and sometimes even for desultory reading or systematic study.

Encouraged by sixpenny-number versions of the national religion and the national history, those with a spare weekly sixpence could acquire additional modern knowledges and modernized old knowledges supplied by increasing numbers of print entrepreneurs emboldened by ending in 1774 of claims to perpetual copyright - a modernizing action recognizing both enlarged market opportunities and relevance of an informed public to national "progress" and imperial competition. ${ }^{25}$ Specialist firms such as Harrison, Bell, and Cooke were soon offering a "modern" multi-volume literary canon of the major genres of belleslettres in weekly sixpenny numbers, larger and less frequent parts, and complete sets. ${ }^{26}$ These were advertised aggressively in proliferating daily and weekly newspapers, apparently targeting the socio-culturally aspirational. ${ }^{27}$ Advertisements promised judicious and wide-ranging literary representativeness, high quality paper, "elegant" illustrations, "modern" typography, suitability of bound sets for home display as furniture books and yet convenient "pocket" size for portability, and cheapness. ${ }^{28}$ For reasons likely more to do with copyright than aesthetic, moral, or ideological value, most authors and works selected came from previous generations. Number-trade sets of belles-lettres advertising superior material quality and stabilized cultural value seem to have appealed to social elites as well as the middling ranks, often appearing in newspaper advertisements for auctions of libraries of deceased or bankrupt "gentlemen," and surviving with gentlemen's or even noblemen's bookplates. ${ }^{29}$

25. This is my interpretation of the events recounted in Mark Rose, Authors and Owners: The Invention of Copyright (Cambridge MA and London: Harvard University Press, 1993), ch. 6.

26. For a thorough account of this trade in poetry, see Bonnell, The Most Disreputable Trade.

27. See James Raven, Judging New Wealth: Popular Publishing and Responses to Commerce in England, 1750-1800 (Oxford: Clarendon Press, 1992), ch. 3, "Booksellers and Markets."

28. See advertisements for Harrison's Novelist's Magazine in the London Evening Post (9 Mar. 1780) [n. p.], Charles Cooke's "Select British Novels" in the London World (23 Oct. 1792) [1], and Tegg's Miniature Novelist's Magazine in Jackson's Oxford Journal (30 Sept. 1809) [2].

29. See "Sales by Auction" ("property of a Gentleman"), London Morning Post (Tue. 12 Apr. 1803) [3]; and "Elegant Library of Books ... property of an Officer of 


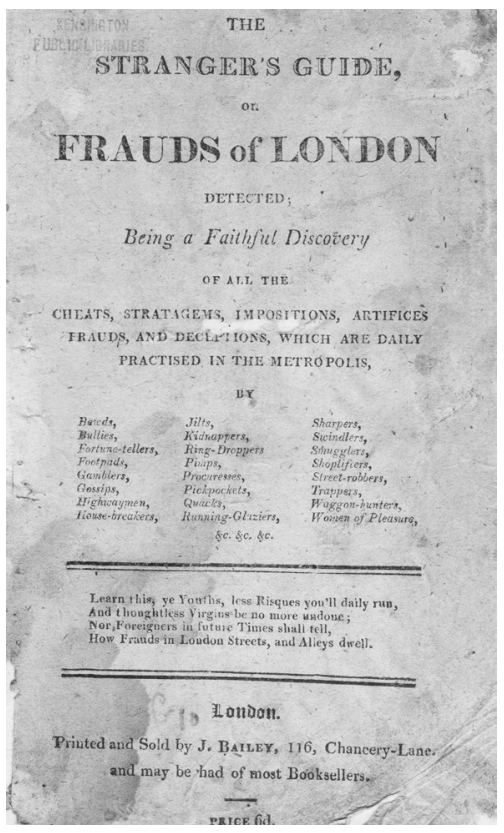

Sensational sixpenny manual of risk and trust: familiar Frauds of London from J. Bailey, who published material similar to Fairburn's Editions.

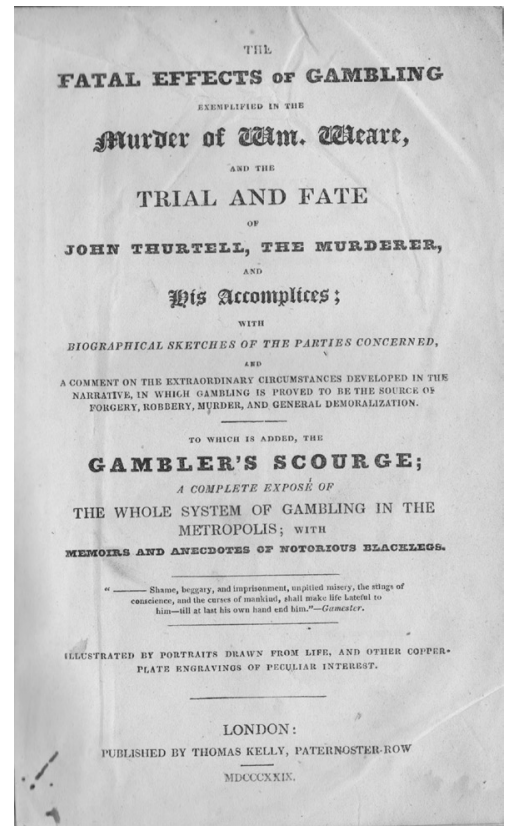

Sensational true crime in sixpenny numbers: the case of John Thurtell (London: Thomas Kelly, 1829).

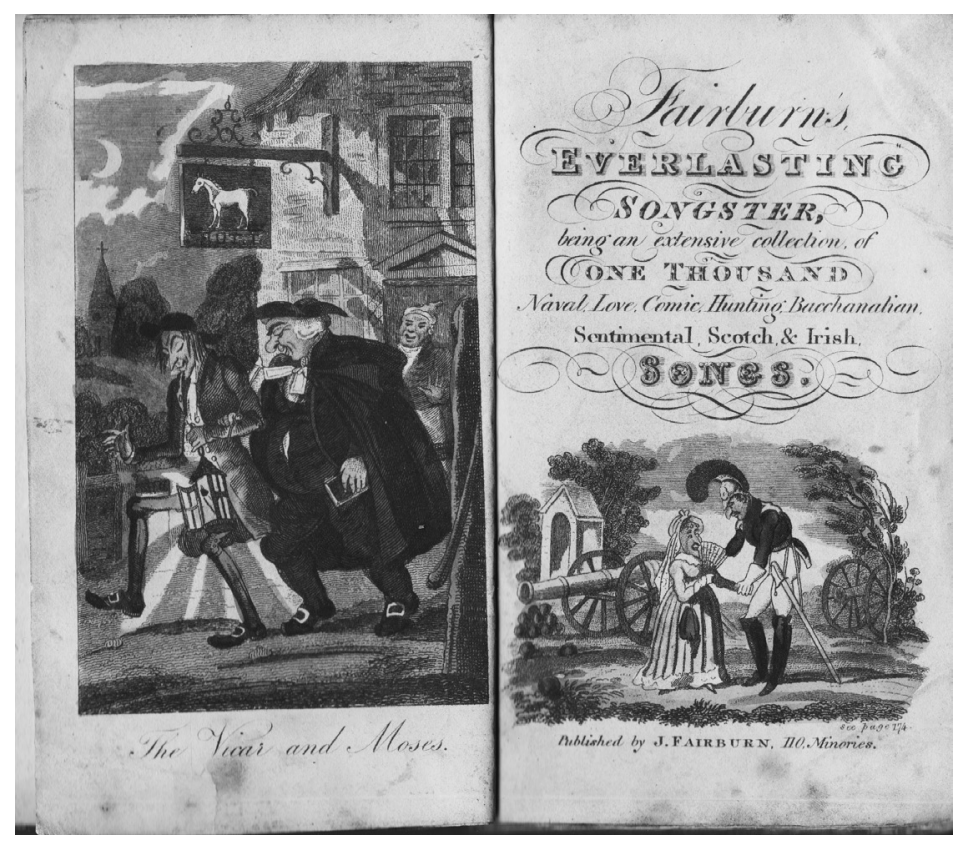

Sociability, satire, and song in sixpenny numbers: The Everlasting Songster (London: J. Fairburn, n. d.). 


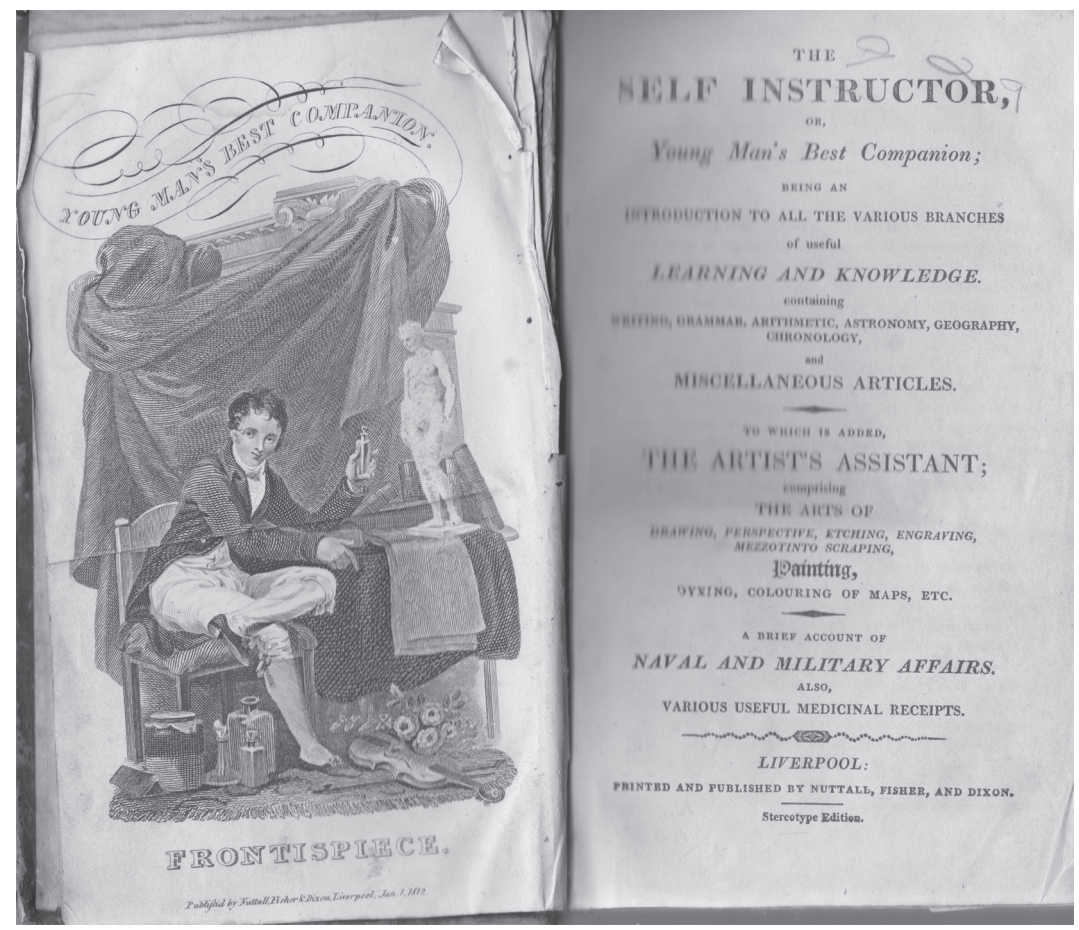

Modern knowledges in sixpenny numbers: The Self Instructor from Liverpool firm Nuttall, Fisher, and Dixon, who produced a list similar to Thomas Kelly's.

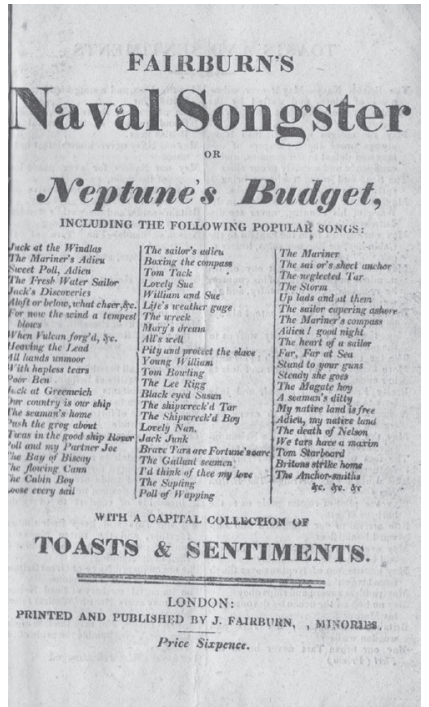

Jolly Jack Tar, icon of plebeian sociability, independence, manliness, and fun.

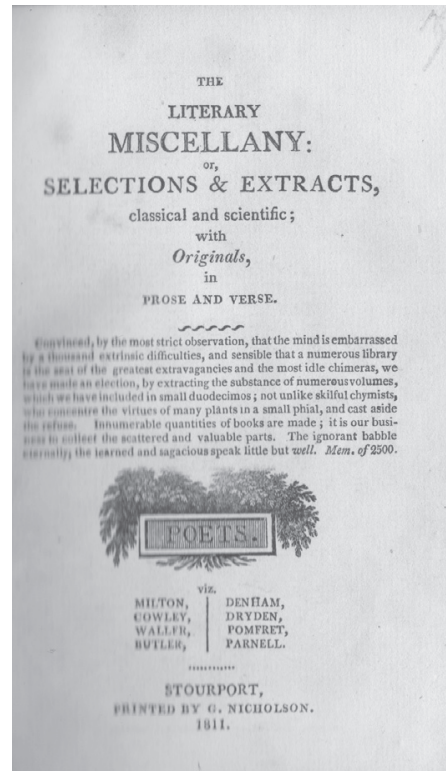

Literary Miscellany: title page for an assemblage-volume of pamphlets of Poets. 


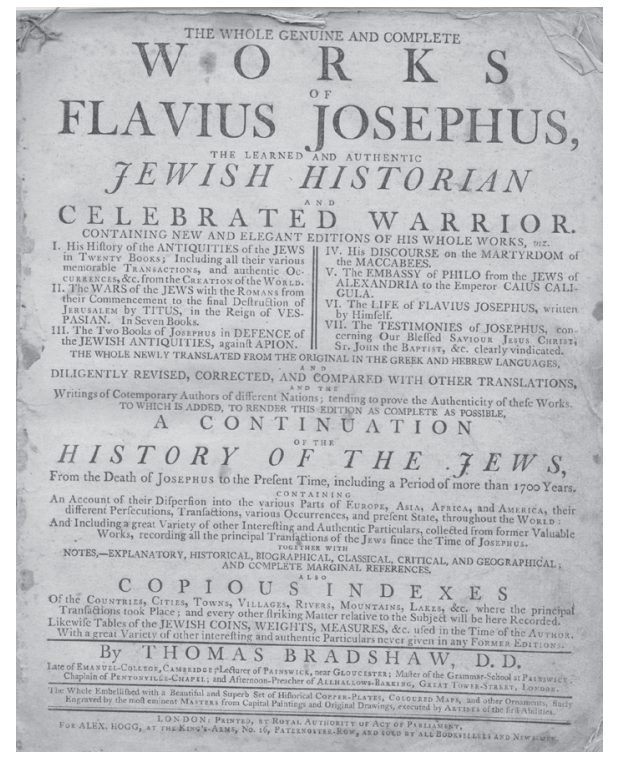

Long-standing sensationalist popular classic in sixpenny numbers: Hogg's edition of Josephus, ancient historian of the Jewish wars.

\section{WORKS of HOMER, \\ The Celebrated GRECIAN POET:}

The ILIAD, and the ODYSSEY;

Thofe very celcbrated and univerfally-admired EPIC or HEROIC POEMS.

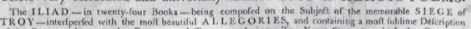

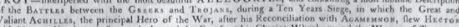

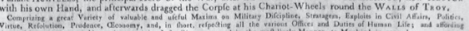

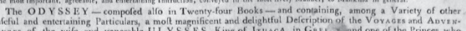

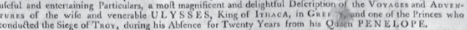
cits The BATTLE of the FROGS and MICE-in THREE Books-

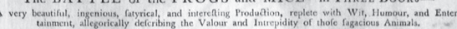
Carefully Tranflated from the Orteisst GREEK.

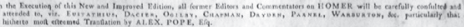
mithe

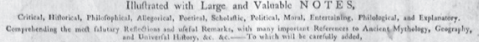

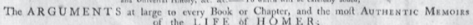

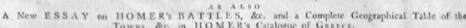

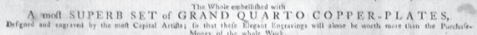

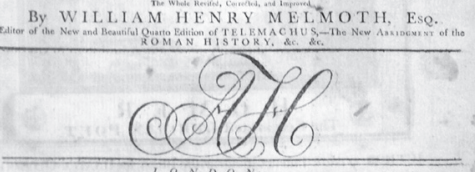

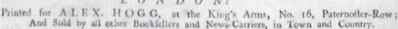
1786

Classical literature as adventure yarns in sixpenny numbers: Hogg's edition of Homer.

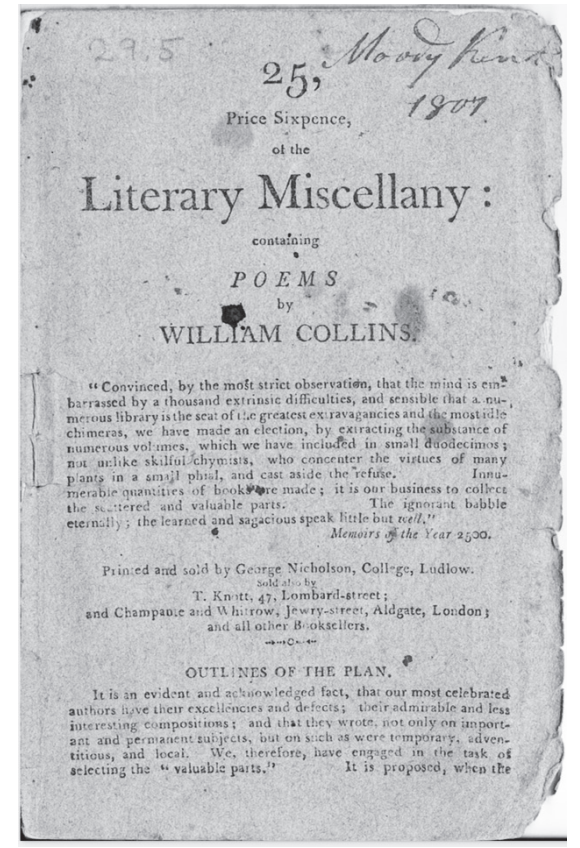

Respectable modern knowledges and culture for around sixpence a pamphlet, to be collected by purchasers into personalized "assemblages": individual issue, part of George Nicholson's Literary Miscellany, published from the 1790 from various locations on the expanding Midlands canal network. 
Appearing less often in such advertisements, seldom found bearing such bookplates, but often carrying subscribers' lists featuring the middling sort were the productions of the mid- to downmarket illustrated sixpenny-number trade in "useful" and "entertaining" modern knowledges. Such specialists had existed for generations and were ever more numerous but the leaders through the onset of modernity were Alex Hogg and Thomas Kelly. From the 1770s Hogg published a wide variety of neo-puritan religious classics, modern and practical knowledges, and sensational and/or titillating non-fiction and fiction works narrativizing neo-puritan modernity. Hogg published several versions of the Bible-with-commentary; Christopher Harvey's pious School of the Heart, originally published in 1647; and a Book of Martyrs after Foxe's sixteenth-century work, long a classic of Protestant martyrology but also sensationalist. Hogg published an exoticist and sensationalist History of the Religious Rites and Ceremonies of all the Nations in the World; more than one History of England; and the long-popular and sensationalist Works of Josephus, classical historian of the revolt of the Jews against the Roman empire. Hogg's useful modern knowledges for managing risk and trust, understanding abstract systems and new chronotopes, and making their possessor feel and seem modern included a Dictionary of Arts and Sciences; a Royal Cyclopcedia; a farming manual; a Collection of Authentic and Entertaining Voyages and Travels; a Geography; and a British Traveller to guide commercial or armchair travellers and configure the modernizing national chronotope. For leisure reading providing sensation with ostensible moral edification Hogg offered the Newgate Calendar and a Collection of Interesting Novels and Romances from the French. Many of Hogg's titles included such words as "new," "complete," "universal," and so on and most were in large (furniture-book) format, illustrated with copper engravings, sold in sixpenny numbers, and "by" authors with genteel-sounding names otherwise unknown to bibliography. With these large sixpennynumber works Hogg published in cheap smaller-volume format,

rank," London Morning Post (Fri. 30 Nov. 1804) [3]; a set of Bell's British Theatre with the bookplates of Robert Hunter of Thurston Manor, Scotland, who was connected to the India trade and Scottish municipal administration; another with bookplates of Lord F. A. Spencer, first baron Churchill of Wychwood, youngest son of the fourth Duke of Marlborough; both sets currently (January 2016) offered on Abebooks.com. 
among others, a New, Complete and Universal Roman History; similar Grecian History; similar History of Scotland; a New and Impartial History of North and South America; a Tables of Interest; a Ready Reckoner; a Letter Writer; an English Physician; a Songster useful for the growing culture of modern sociability; more than one Jestbook for private and sociable entertainment; more than one Frauds of London; a Story Teller, a Spouter (anthology of recitation-pieces for semi-formal sociability); a Lover's Guide; more than one cookery book; a Farmer's Wife (manual of modern housekeeping); a Pigeon Fancier; and a Pamela, Clarissa, and Charles Grandison.

Taken altogether, here was an illustrated library for fashioning a petty-bourgeois self, sociability, and modernity. There were guides to religiously based self-fashioning and ostensibly "comprehensive" guides to practical modern knowledges. There were templates for amorous, sociable, and business communication and conduct and manuals of commercial practice and household management when home and business were often adjacent. There were representations of the "national" and imperial chronotope from barbarous past to modernizing present and local to global. There were handbooks for diverting yet useful avocations and aids to modern sociability. There was "true crime" representing an older moral economy based on a lottery mentality of opportunism, luck, and innate gifts but now ostensibly warning against failure to acquire a modern investment mentality of self-discipline and moral, intellectual, and vocational capital reinforced by religious piety. There was a corresponding kind of titillating-moralizing fiction such as Richardson's novels, which would later be touted by Anna Laetitia Barbauld as foundation of the specifically modern novel. These embodied a more recently formed myth of self-disciplined selfhood surviving vicissitudes (presumably more interesting when involving sexual peril) and enabling social mobility and even gentrification. By the early nineteenth century shorter versions of Hogg's list were being published by others in London and in modernizing provincial centres by firms such as Gleave in Manchester; Nuttal, Fisher, and Dixon in Liverpool; and Mackenzie and Dent in Newcastle upon Tyne. But Hogg's greatest imitator was in London and a former employee.

Hogg's one-time shopman Thomas Kelly eventually took over Hogg's business premisses and his line of products and modernized 
and expanded its scope..$^{30}$ Kelly had acquired business discipline and acumen steadied by the same neo-puritan religious literature and modern knowledges that Hogg had and Kelly soon would distribute across the nation. Kelly further modernized by refining both the physical appearance and socio-cultural standing of the sixpennynumber trade he had learned from Hogg, likely responding to his readership's demand for forms of improved cultural capital according with their growing sense of distinctive and respectable cultural citizenship. Kelly did so by modernizing typography and design in the style of the mid-market specialists in "elegant" belles-lettres such as Bell and Cooke; by applying new technologies such as stereotyping; by retaining many elements of Hogg's list and augmenting them with additional modern history, modern fiction, and modern knowledges; by employing professional journalists and popularizers rather than the genteelly named but unknown hacks favoured by preceding generations of number-trade specialists; by improving quality of illustrations; by exploiting an improving transportation infrastructure to market his publications nationally through a network of travelling subscription agents; and by carefully and publicly distinguishing his form of sixpenny print from that of reformist journalists and sixpenny polemicists on one hand and on the other hand certain publishers specializing in a wide range of sixpenny pamphlets, such as the firm of Fairburn. In this process Kelly became rich and Lord Mayor of London, while training a new generation of imitators and competitors through his employment of provincial agents.

The Fairburn firm was led by successive family members from at least the 1790 os to the 1840 and offered a distinctive sixpenny modernity incorporating elements and texts from historic plebeian customary culture, now attached to contemporary political issues and information. Alongside and sometimes in congers with similar firms such as J. Bailey and Hodgson, Fairburn operated between the likes of Hogg and Kelly on one hand and on the other the number-trade specialists in multi-volume "British" classics such as Harrison, Bell, Cooke, and their successors. Fairburn seems to have addressed a readership more

30. C. R. Fell, Passages from the Private and Official Life of the late Alderman Kelly, with Extracts from his Correspondence (London: Groombridge and Sons, 1856), 32, 92. 
reformist-oriented and plebeian and more interested in or restricted financially to cheap occasional rather than serial publications. Fairburn also published maps, numerous prints ranging from sentimental through loyal-patriotic to satirical-reformist, prints of popular actors in character, and books for youngsters. Fairburn published several shortlived reformist and satirical periodicals, such as the Gorgon edited by John Wade, and some books in sixpenny serial numbers, such as Wade's Black Book (1820) recording state sinecures and elites' emoluments; David Carey's Life in Paris (1822), imitating Pierce Egan's recent enormously successful fictional manual of fun Life in London; journalistic accounts of political and sensation-crime trials, including one apparently commissioned from the young Charles Dickens; ${ }^{31}$ and an unsuccessful multi-volume biography of Napoleon.

Fairburn's main line, however, was the individual sixpenny pamphlet, often headed "Fairburn's Edition" as a unique brand and megatext marker. These editions offered buyers a distinctive modernity combining historic customary culture with modern knowledges and contemporary issues and abbreviated versions of sensationalist contemporary literature, in correspondingly fashionable and flashy format. Fairburn's list comprised a megatext distinct from the purposeful rejection of both unmodernity and socio-culturally aspirational modernity in the appropriately more respectable-looking and substantial formats from Hogg and Kelly. "Fairburn's Editions" taken together retain elements of historic plebeian lottery mentality of luck and opportunism based on long experience of subsistence economy, consolidated into "customs in common," and articulated as insistence on customary economic, social, and political "rights." Fairburn's megatext does not reject modernity for this customary culture but rather expresses a distinctive version of it, formed in a process that has been described, controversially, as "the making of the English working class." 32 Judging from Fairburn's megatext, this modernity was less individualistic and

31. See Ruth Richardson, “The Italian Boy: early journalism by Charles Dickens,” British Library, Collection items, referring to Fairburn's Burking the Italian Boy (1831) http://www.bl.uk/collection-items/the-italian-boy-early-journalism-by-charles-dickens

32. See Bob Bushaway, By Rite: Custom, Ceremony and Community in England 1700-1880 (London: Junction Books, 1982); and E. P. Thompson, Customs in Common: Studies in Traditional Popular Culture (New York: New Press, 1993) and The Making of the English Working Class (London: Gollancz, 1963). 
more sociable, interested less in respectability and more in fun, and less chary of exposing and mocking the unmodernity of the established order than were the modernities offered in Hogg's and Kelly's megatexts or the "British Classics" of Bell, Cooke, and Barbauld. Likewise, "Fairburn's Editions" positively plebeianized upmarket modern literature and culture in several ways. Typically illustrated with lively frontispieces resembling his numerous separate graphic prints, they reformulated versions of fashionable modern sentimental and sensational literature and entertainments into a distinctive urban and plebeian culture of cozy domesticity and hearty sociability, avocations and fun, intense interest in current events and politics, and satirical or indignant views of the establishment and their political order. Fairburn's megatext was secular (often anti-clerical) and immediate, offering little religious or historiographical literature, showing no interest in an emerging "national" literary canon of use to elites and those aspiring thereto, and engaging a broader range than did Hogg and Kelly of topics likely to interest a readership among increasingly politicized lower ranks.

Alongside sixpenny manuals for practical modern knowledges and in similar ostentatiously modern appearance Fairburn published supposedly unmodern knowledges such as fortune-telling and dream books. With brief versions of the usual business and correspondence manuals Fairburn published summaries of new legislation affecting artisans and shopkeepers. Fairburn consolidated past and contemporary popular fiction distinctively. Rather than the selection of earlier novels recirculated in "elegant" modern format by the likes of Harrison, Cooke, and Bell on one hand and Hogg and Kelly on the other, Fairburn published, in more extravagantly modern dress, historic street-literature chapbook-fiction favourites alongside abbreviations of successful "modern novels" and theatre pieces in sentimental, Gothic, historical, melodramatic, and pantomime genres. Similarly, for true crime Fairburn offered favourites from the old-style Newgate literature alongside detailed journalistic accounts of contemporary trials for murder, treason, and "crim. con.," or adultery in high society. Fairburn addressed lower ranks' concern with enhanced risk and trust created by modern abstract systems from finance to government with pamphlets on frauds and swindles and guides to commercial legislation, but also with fiction featuring sentimentalized protagonists 
overcoming such risks. Alongside jestbooks of familiar type but updated with contemporary references, Fairburn offered plays and burlesques with similar saucy humour and topicality. Fairburn published a wider range than Hogg of manuals for popular sports and pastimes, appealing to plebeians and petty bourgeoisie increasingly interested in hobbies and fun of their own kind, in their interests. Such militantly entertaining material could have serious and political uses: defying the growing earnestness of elites' modernity; asserting the people's "right" to fun in face of increasing upper- and middle-class attempts at social surveillance, policing, and control; and engaging a larger and distinctive world of commercialized sixpenny fun such as theatre, entertainments, music and song, sports, and spectacles that became the popular culture we still know.

Fairburn's indirectly political or apparently apolitical material shaded into and in important respects resembled the explicitly political. This usually mocked or denounced the dominant classes and their social, economic, and political modernity. From the Revolutionary and Napoleonic crisis to the Reform Bill debate, Fairburn and similar firms addressed a coalition of politicized and mobilized elements of the lower and middle ranks as the political nation-in-waiting. Fairburn produced sixpenny verbal and graphic print that incorporated, as had such plebeian reformists as Tom Paine and Thomas Spence, general oppositional elements of historic popular street literature applied to current events, especially scandal in high places, as in political burlesques using familiar nursery rhymes and the pro-Queen Caroline satire Jack and the Queen Killers. ${ }^{33}$ There were satirical news pamphlets on events such as the trials of the Nore naval mutineers and newsy accounts of Nelson's funeral (Fairburn and his like heroized the figure of Jack Tar), the assassination of prime minister Spencer Perceval, and the 1811 comet. The "radical vocabularies" and "melodramatic mode of representation" of such literature has been linked to Victorian writers such as Dickens. ${ }^{34}$ More important, the sixpenny pamphlets of

33. See Marcus Wood, Radical Satire and Print Culture 1790-1822 (Oxford: Clarendon Press, 1994), 215; Iain McCalman, Radical Underworld: Prophets, Revolutionaries and Pornographers in London, 1795-1840 (Oxford: Clarendon Press, 1993), 205-7, 221-22.

34. Sally Ledger, Dickens and the Popular Radical Imagination (Cambridge: Cambridge University Press, 2007), 13. 
Fairburn and his like probably provided suitable print matter for those engaged from the 1790 in the politicized sociability, the debating clubs, associations, and conversation, where a certain modernity was being formulated as a certain vision of "reform," 35 mobilized in demonstrations by men and women at Spa Fields London in 1816, at "Peterloo" Manchester in 1819, in favour of Queen Caroline and against her husband and his regime in 1820, for the Great Reform Bill in the early 1830 , and at Chartist assemblies later.

Meanwhile, from the 178 os and successive locations on the expanding Midlands canal network, the innovative printer, publisher, "compiler" (as he termed himself), and author George Nicholson created a purposefully distinct sixpenny print culture. ${ }^{36}$ His "Literary Miscellany" was issued in pamphlets priced by length but around sixpence. Thus distinguished, it differed further from the likes of Hogg's sixpennynumber volumes of older texts, Kelly's similar but more up-to-date publications, Bell's and Cooke's sixpenny-number volume sets of fulllength "British Classics," and Fairburn's sixpenny-pamphlet megatexts. Nicholson's "Miscellany" comprised religious-devotional, educational, moral, ethical, practical, and "entertaining" works in verse, fiction, and instructional prose redacting the literature of modern selfhood, relationships, lifestyles, and knowledge mainly from the 1760 s to 1790 , from Sterne to Wollstonecraft. Nicholson's megatext looks smartly not ostentatiously modern, circulated modern knowledges of an ostensibly genteel kind, asserted a moderate reformism more social and cultural than expressly political, and offered genial "humour" rather than scabrous satire. It was well printed on good paper with fresh fonts and elegant illustrations by outstanding artists using high quality copper engravings but also the new technique of boxwood engraving that enabled delicate and detailed small-scale effects. Comparatively, the "Miscellany" seems designed to offer an elegantly modern-looking manual of modernity for the plebeian but socio-culturally aspirational who were creating and leading industrialized, commercial, and administrative modernization: one complete set (now in the British Library)

35. Jon Mee, Conversable Worlds: Literature, Contention, and Community 1762 to 1830 (Oxford: Oxford University Press, 2011), 24.

36. See Audrey Cooper, George Nicholson Printer at Stourport (Stourport: Stourport-on-Severn Civic Society, 2001). 
was owned by the family of Jedediah Strutt, wheelwright turned wealthy inventor of textile machinofacture.

How users created sixpenny-print's meanings in and for their everyday lives and their self- and social fashioning is glimpsed in workingclass autobiography, though a genre spurred by desire to recount acquisition of a certain modernity and hence inherently self-serving. ${ }^{37}$ Thomas Carter, born to a farm labourer in 1792 , was allowed by a woman who sold cakes, fruit, and books-in-numbers to read, likely in numbers-form, the Bible, Pilgrim's Progress, and Hervey's Meditations among the Tombs. ${ }^{38}$ John Clare, poet and farm labourer born in 1793 , was as a youngster widely and deeply read in historic chapbook street literature, modern sixpenny pamphlets, and, when he could get them, books in numbers, such as stray issues of the popular classic Josephus's history of the Jewish wars, Barclay's Dictionary, and Thomas Kelly's Geography, and a number-trade edition of Dialogues between a Pilgrim, Adam, Noah, and Cleophas subscribed to by his mother. Thomas Cooper (1805-92), Leicestershire shoemaker, labour activist, Methodist preacher, Chartist organizer, and poet and novelist, as a youth in the 1810 s could not afford books but was given stray issues of various works by a travelling "number-man," enabling him to acquire fragments of modern knowledges alongside historic street literature, modern pamphlet fiction, and number-trade neo-puritan classics. ${ }^{39}$ Thomas Frost, Chartist, journalist, and novelist born in 1821 to a reformist tailor, recalled sixpenny print in his youth including historic chapbook favourites, Fairburn's Editions, reformist political pamphlets, and numbertrade modern knowledges such as those mentioned earlier. ${ }^{40}$ More such readers could be cited.

The publishing revolution that served them through modernity's onset was extended through the nineteenth century and beyond, enabling sixpence to remain a major price point in the convergence of print culture and politics in the modern state as a field of contest

37. See David Vincent, Bread, Knowledge and Freedom: A Study of NineteenthCentury Working Class Autobiography (London: Europa Publications, 1981).

38. [Thomas Carter,] Memoirs of a Working Man (London: Charles Knight, 1845), 20 .

39. Thomas Cooper, The Life of Thomas Cooper, Written by Himself (London: Hodder and Stoughton, 1872), 22, 33.

40. Thomas Frost, Forty Years' Recollections: Literary and Political (London: Sampson Low, Marston, Searle, and Rivington, 1880), 77-79. 
between different interests, and enabling sixpenny (or less) print to be used by those disparate interests in creating their own lives, communities, cultures, and politics. Successors of the likes of Fairburn, such as G. W. M. Reynolds, John Dicks, and Edward Lloyd, could merge plebeian modernity, entertainment, and politics in full-length books rather than pamphlets. Successors of Nicholson, such as George Bell, Bohn, Routledge, Collins, Blackie, and Nelson, could offer full-length books of respectable and "useful" knowledge in entertaining form for the socially, culturally, and politically aspirational. Successors of the likes of Bell, Cooke, Hogg, and Kelly, such as Cassell and Chambers, continued offering multi-volume respectable popular modernity as furniture books in sixpenny or cheaper weekly numbers into the twentieth century. But anxiety among upper and middle ranks over sixpenny print increased with successive extensions of the electorate and expansion of literacy and access to print. By 1830 one commentator disdained as "sixpenny sciences" the publications of the Society for the Diffusion of Useful Knowledge, in cheap serial numbers designed to detach plebeian readers from the likes of Fairburn's Editions. ${ }^{41}$ After the 1832 Great Reform Act another commentator deplored advent of the "age of paper" (presumably further decline from the gold, silver, and bronze ages of civilization) with its dangerously intoxicating "penny wisdom and sixpenny science" for the many. ${ }^{42}$ Soon after the 1867 Reform Act a commentator predicted that the "sixpenny novel" would soon destroy Mudie's circulating library and the respectable middle-class literature it purveyed. ${ }^{43}$ As one print historian recently put it, "Victorian moralists often complained that their less well-off countrymen read mostly rubbish, and they were right," mercial and legal restrictions prevented the "less well-off" from getting anything supposedly "better."

Integrational linguistics and effective semiotics would argue that "rubbish" is meaning and value attributed to, not inherent in an object.

41. M. D. H., Answer to a Letter from the Secretary of a Society for Political Instruction, Formed by Working Men, Asking for Advice on the Conduct of Such Institutions (London: Effingham Wilson [1830]), 8.

42. "Blessings of 'Useful Knowledge," Essex Standard (Colchester, Sat. 8 Feb. 1834) [2].

43. Cheltenham Looker-on (Sat. 24 July 1869), 472.

44. St Clair, Reading Nation, 356. 


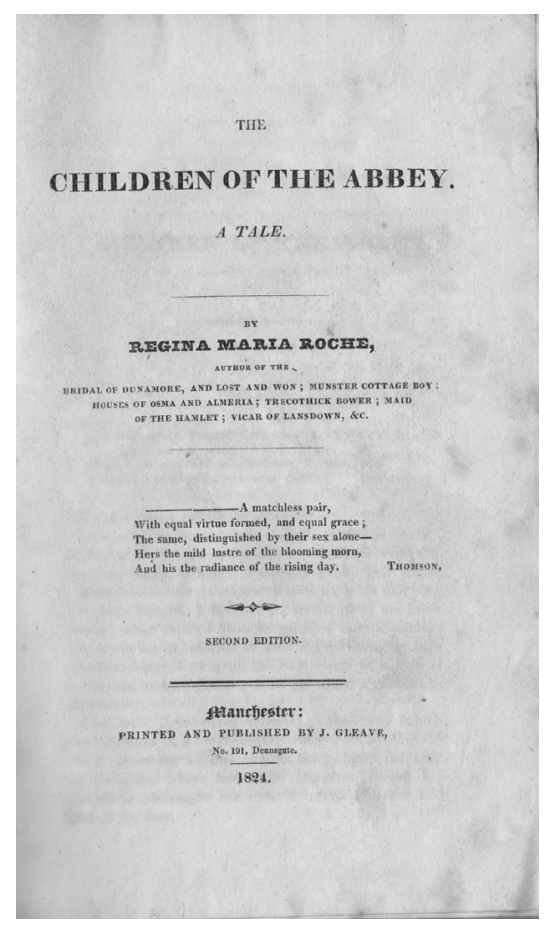

Gothic novel bestseller reprints in sixpenny numbers: The Children of the Abbey from Gleave of Manchester, who published a smaller version of Thomas Kelly's list.

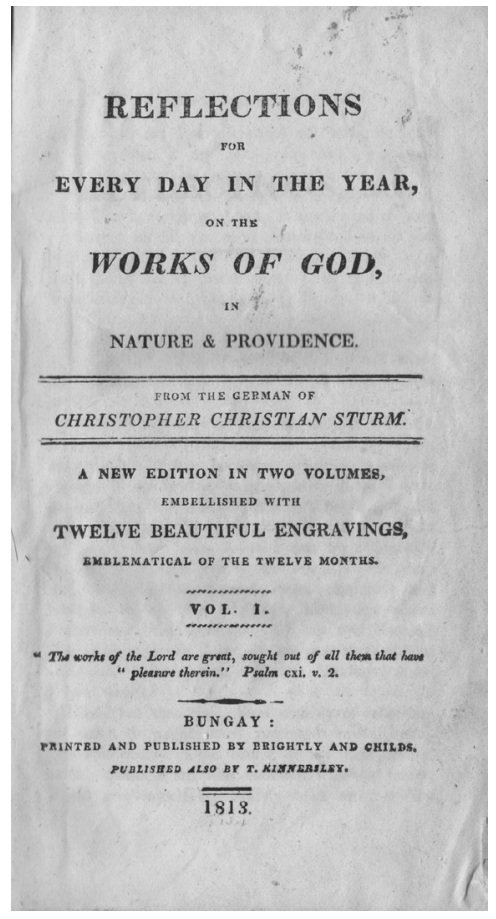

Romantic neo-puritanism in sixpenny numbers: Sturm's Reflections from the Bungay firm of Brightly and Childs, who published a shorter version of Kelly's list.

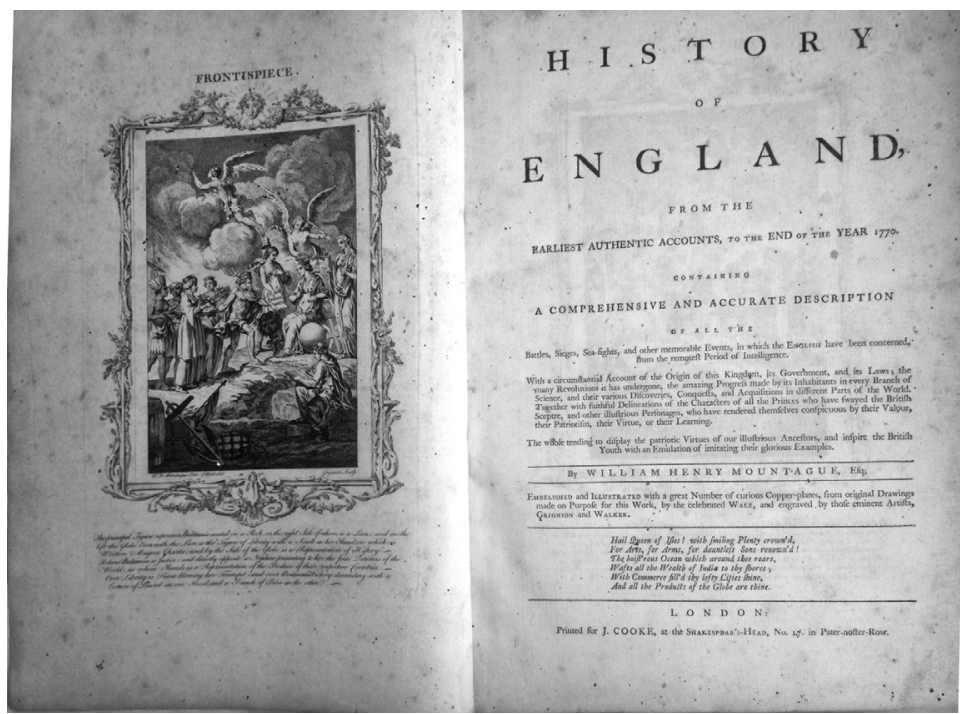

Modern "national" history in sixpenny numbers with sensationalized illustrations: "William Henry Mountague," History of England from J. Cooke, number-trade specialist similar to Alex Hogg. 


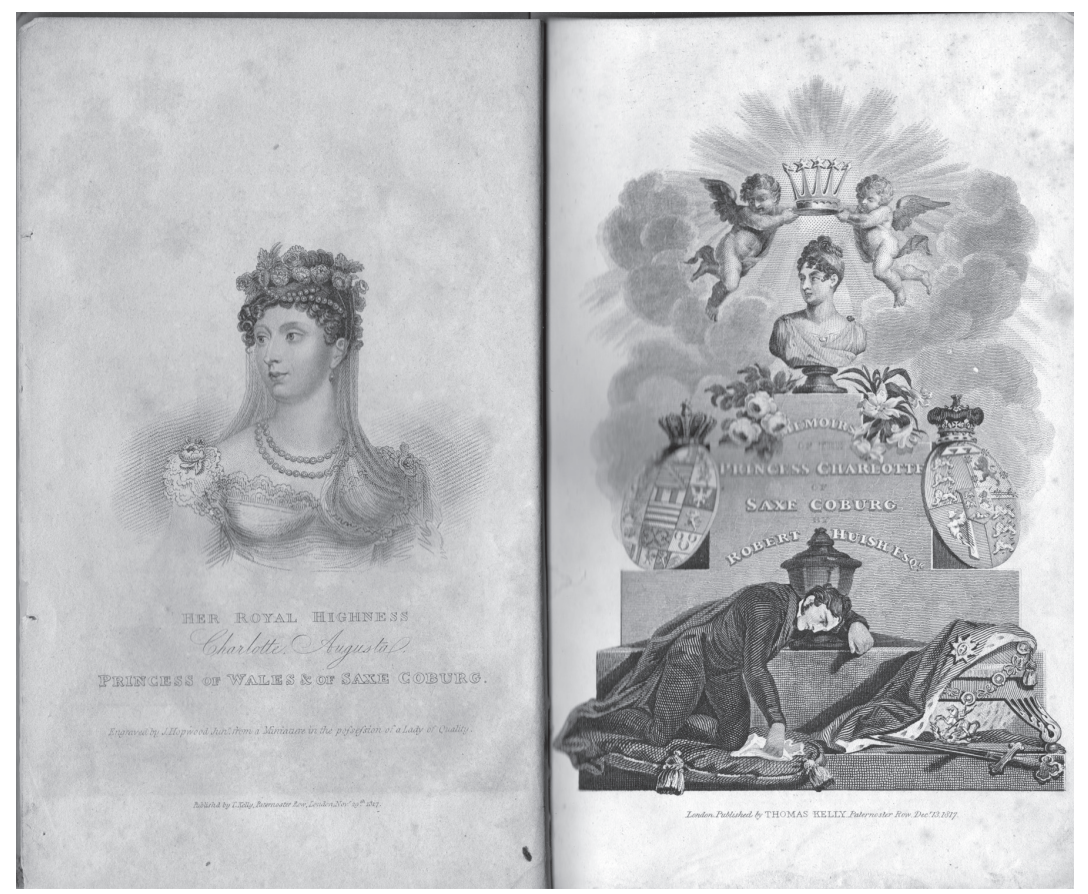

News and royal biography in sixpenny numbers: Thomas Kelly's edition of the life of the late Princess Charlotte.

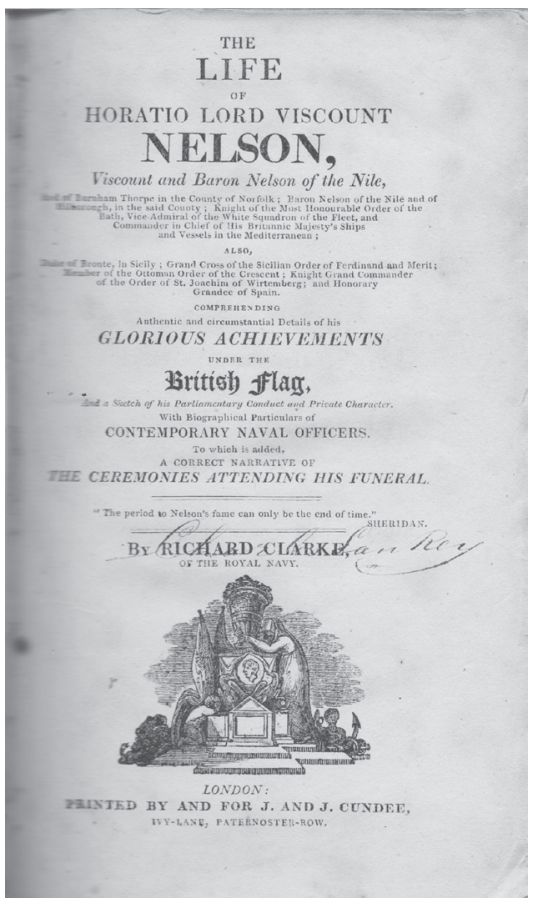

Modern heroes in sixpenny numbers: Cundee's Edition of the life of Nelson. 
One person's “rubbish” may be another's superlative aid to self- and social fashioning, among other things possibly for a sense of cultural citizenship to share with others, inform ideas of political citizenship, and validate political activism. People make meanings from cultural objects not, as most academic accounts still assume, controlled or influenced by objects' creators through telementation, nor as "consumption," nor as part of some "mass," nor under some "regime" of reading administered by institutions, nor constrained by some "interpretive community." Rather, people make meanings creatively as individuals in unique moments, for their own purposes, using all they are and know at that moment, in their own interests, as only they can know them, in and for their everyday lives. "Reading-in-a-classroom" ${ }^{45}$ is not the same as and cannot trump such reading, and even readers' accounts of their meaning-making cannot be the same as such meaning-making, which meaning-makers themselves can only recreate provisionally, not reproduce, in language. We must speculate provisionally on those uses with the means available, including collections of surviving print objects, histories of the production and circulation of such objects, cultural and other kinds of history, accounts by readers, disciplinary interpretive practices, and whatever else may come to hand for the purpose. During modernity's onset and long after, sixpenny print's users assigned it meaning and value as such for better and worse; it circulated in and as megatexts of various content and configuration by publisher-booksellers with different agendas or addressing different readerships; it was read as distinct megatexts or eclectically across megatexts; and it was deployed by its users, even when unread. for various kinds of self- and social fashioning, enabling formation of different or syncretist kinds of cultural citizenship in the political contest to define and dominate modernity and the modern state.

45. McHoul, Semiotic Investigations, 65 . 